\title{
AN EMPIRICAL ANALYSIS OF MONETARY MEASURES TAKEN BY STATE BANK OF PAKISTAN TO CATER THE CATACLYSMIC IMPACT OF COVID -19 ON THE ECONOMY OF PAKISTAN
}

\author{
Usman Rasheed \\ Bahria Business School \\ Bahria University, Islamabad, Pakistan
}

\author{
Dr.Mohsin Raza \\ Bahria Business School \\ Bahria University, Islamabad, Pakistan
}

\begin{abstract}
COVID-19 has posed an unprecedented challenge to the economies of the World. Besides safeguarding sustainable financing for health, Governments were struggling to ensure the economic and financial sustainability of their countries. The role of the central banks was critical in this regard and they were under severe pressure to save the economy from the catastrophic impact of Covid-19. Using their mandate, the central banks across the countries took monetary measures to avoid the economic meltdown. This paper discusses the measures taken by the State Bank of Pakistan to save the economy from the adverse effect of COVID-19. The analysis shows that the steps taken by the central bank of Pakistan were pertinent and lead to stabilizing the dwindling economic situation. Decreasing policy rate, injecting liquidity in the economy, granting loans contributed towards steadiness of households and the business community. Jobs protection scheme was particularly savior for the daily wages who lost their jobs due to pandemic. Further relaxing credit requirements for exporters and importers keep intact the supply chain for necessary items. The findings of the study are specific to Pakistan however the same can be generalized as the steps taken by the Central bank of Pakistan are widely applicable.
\end{abstract}

Keywords - Monetary policy and COVID-19, Monetary measures and pandemic, Central bank's monetary measures.

\section{INTRODUCTION}

Historically pandemics have a long-lasting impact on the economies and lead towards substantial measures to liberate the economy. In the twentieth century, pandemics like the Spanish Flu (1918-1920) and Asian Flu (1957-1958) have tested the nations. The twenty-first century has witnessed Swine Flu (2009-2010), West African Ebola (2014-2016), and Zika Virus (2015-present day). Recently COVID-19 pandemic has emerged as the biggest challenge to the global economy (The Economist, 2020). Fed Chairman Jerome Powell summarized the current economic situation in his November 12th speech "The Covid-19 pandemic brought the economy to a screeching halt, and while it has started its long road to recovery, the economy we knew is probably a thing of the past. We're recovering, but to a different economy". Ironically the pandemic has proven to stay for a considerable if not for a long period and will keep testing the economies of the world. It is projected that COVID-19 will reduce the global GDP growth rate by $1.5 \%$ (OECD, 2020).

At the start, the dynamics of the pandemics were unknown and caused unfamiliar challenges to the economies. Lockdowns on global scale led to a prompt stop in economic activities in a major part of the world. Containment measures further derailed the economies by bringing the production of goods and services to the halt. As a consequence, the local and global supply chain disrupted badly. To save the economy the policy reactions by the Governments, central banks, and supervisory authorities were unprecedented. They have responded decisively and took bold steps to liberate the economy. Especially, massive and extraordinary policy actions were taken by central banks to prevent the financial collapse and to lubricate the economic wheel.

Like the rest of the world, the coronavirus pandemic triggered momentous adversities and interruption to economic activities in Pakistan. The economy of the country was in mild depression before COVID-19 and the pandemic has made the situation worse by reducing the economic activities significantly. Despite the mediocre economic situation and malaise financial standings, the State Bank of Pakistan (SBP) has taken a number of aggressive policy actions to mitigate the economic effects and to stabilize the tumultuous economy under pressure from the novel COVID-19. Pre-emptive and pragmatic monetary policy measures helped to dampen the impact of Covid-19 in the country as compared to many other 


\section{International Journal of Engineering Applied Sciences and Technology, 2021 \\ Vol. 6, Issue 1, ISSN No. 2455-2143, Pages 99-105 \\ Published Online May 2021 in IJEAST (http://www.ijeast.com)}

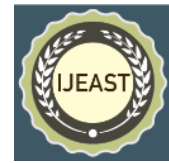

emerging economies. This article briefly summarises how SBP mitigated the adverse effect of COVID-19 on the economy by taking monetary measures. Further, the article discusses the repercussions of these monetary measures on Pakistan's economy.

The specific question the study intended to find the answer is how the monetary measures taken by SBP resuscitated the economy from the catastrophic impact of the pandemic. Tackling this question is indispensable as it will help government regulators to take learned decisions in the current situation and to devise the monetary policies to aptly respond to the future crisis. Monetary measures in this article encompass change in policy interest rate, loan extension \& restructuring package, temporary economic refinance facility (TERF), employment protection scheme (SBP rozgar scheme), refinancing facility to combat Covid-19 (RFCC), digitalization of Payment Mechanisms and operating procedures, and relaxing credit requirement for importers and exporters.

The paper is organized as follows. The next section concisely outlines the policy reactions by central banks to cater to the pandemic; followed by the monetary measures taken by the State bank of Pakistan (SBP) and the last section concludes the paper.

\section{POLICY REACTIONS By CENTRAL BANKS}

Throughout history financial crises required central banks around the world to break the cycle of the heightened risk of distress in financial markets, liquidity freezes, and declines in the real economy. During the global financial crisis of 20072008, central banks injected liquidity into the economy of their respective countries by the provision of liquid assets to commercial banks and wholesale markets. Central banks altered the characteristics of their monetary operations to relieve liquidity stress. The starring role of the central bank as provider of market liquidity during the times when financial markets have become chaotic and illiquid is referred as market maker of last resort (MMLR). (Buiter, 2008) evaluate and assess the effectiveness of liquidity provision policies of several central banks, including the ECB, the BOE, and the Fed during the crisis. During the early 1990 Bank of Japan also took similar measures to boost up the economic activities when the collapse of asset prices stressed the country's balance sheet. Central banks throughout Latin America have provided systemic liquidity in response to several banking crises in the region since the mid-1990s (Jácome, 2008).

The policy reactions by central banks to the current crisis though extraordinary and unprecedented but replicated the traditional policy directives of central banks to meet their core objectives by easing financial conditions to support their economies. Central banks responded quickly and influentially to current economic and financial challenges posed by the pandemic, in accordance with their mandates to ensure smooth market functioning and effective transmission of monetary policy. Many of the new central bank programs were envisioned as "cushion the blow" policies to endure credit materialization, support the real economic activities by easing financial settings, provision of liquidity, and decreasing financial ache (Mosser, 2020).

Central bank policy actions can be generally broken into three categories: monetary policy, liquidity provision, and besieged credit programs focused to support non-financial sector players, firms, households, and municipalities. Notably, these actions are escorted by mammoth regulatory relief actions, including slackening of capital and liquidity standards, and relaxing of market regulations and activity restrictions in the financial sector, with the intention to make financing more accessible at a lesser cost. (Mosser, 2020) When the financial conditions began strict in March 2020, central banks swiftly injected liquidity through market operations, purchased government bonds to support market functioning, and launched numerous emergency facilities to revive the economic activities. The measures taken by central banks highlighted their crucial role in crisis management as they swiftly cut policy interest rates, introduced new or expanded asset purchase programs, large-scale balance sheet measures, credit schemes having lower interest rates to support the flow of credit to households and businesses.

\section{Monetary Measures TaKen by the State Bank} OF PAKISTAN

\section{A. Change in policy interest rate}

The economic history of many countries advocates that conventional astuteness about monetary policy endures sizeable changes during major events such as financial panics, depressions, and wars (Cukierman, 2013). Condensing monetary policy rates in recessions is a customary practice, almost every central bank on the planet has abruptly cut policy interest rates (Kelly Mua Kingsly, 2020). Central Banks have bowdlerized interest rates to historic lows to decrease the hostile effect of COVID-19. Expansionary monetary measures were espoused by several central banks to arouse the economy through interest rate alterations (Peterson Ozili, 2020). This alteration provides immediate cash flow stimulus to businesses and households by extending the cheap finance and decreasing the cost of interest payments and thus saving the risk of bankruptcy of marginalized businesses. Reduced interest rates also increase the supply of money, support economic activities by increasing incentives to invest and consume, and dipping incentives to save.

The Fed's Federal Open Market Committee (FOMC) lowered the federal funds' target range 150 basis points to 0 to 0.25 percent (FED, 2020). While the Monetary Policy Committee (MPC) of the BOE lowered their bank rate from 0.75 percent to 0.10 percent (BOE, 2020), the Bank of Canada ( Banque du Canada) has lowered the interest rate to 0.25 Percent (BOC, 2020) and the Central Bank of Colombia reduced the monetary policy rate by 250 basis points (CBC, 2020) in order 


\section{International Journal of Engineering Applied Sciences and Technology, 2021 \\ Vol. 6, Issue 1, ISSN No. 2455-2143, Pages 99-105 \\ Published Online May 2021 in IJEAST (http://www.ijeast.com)}

to support the economic activities and to facilitate the consumer and business to stem the financial impact of COVID-19. The European Central Bank (ECB) and the BOJ's (Bank of Japan) main policy rates were already around zero and remained unchanged.

Like the rest of the world, SBP has also condensed the policy rate since the flare-up of the pandemic to diminish the burden of impending interest payments on businesses and households. The SBP has condensed the policy rate by a cumulative 625 basis points from 13.25 percent to 7 percent in a short period from mid-March to June 2020 (SBP, 2020). This is one of the prevalent reduction in the policy rate amongst the developing economies during the Pandemic. The Bank cut interest rates to pre-empt funding restraints in financial markets and to ease the spread of monetary policy to the real economy (Kelly Mua Kingsly, 2020) The foremost factor stimulating a violent reduction in the policy rate was a shrill tumble in inflation and relentless economic slowdown. During the perplexing times, the emphasis of monetary policy shifted toward supporting growth and employment. Recently, in its meeting held on 21st September 2020, the SBP decided to retain the policy rate unchanged at 7.0 percent. Taking note of the improved outlook for growth and rising inflation, SBP views that present monetary policy deportment is suitable to upkeep the emerging retrieval while keeping inflation prospects wellanchored and preserving financial steadiness (SBP, 2020)

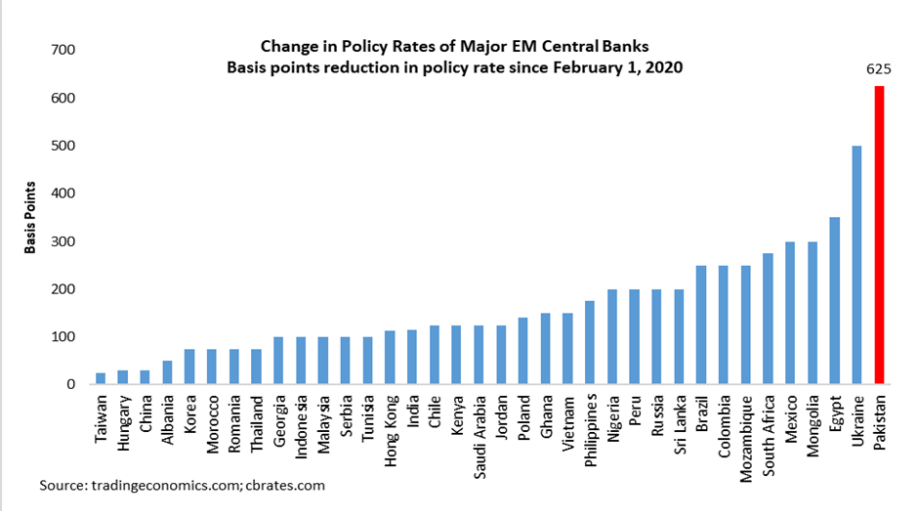

Fig.1. Change in Policy rate by major central Banks

But the change in policy rate was not sufficient to stimulate fresh investments and the economy. Secondly, it can be argued that with the economy overloaded with taxes in recent years, especially after the start of the IMF program, the existing policy rate of 7 percent is still on a higher side. As observed in many other countries the policy rate reduction by the central banks, unable to engage in economic activities because governments had imposed social distancing constraints amid fear of contacting the coronavirus during the eruption (Peterson Ozili, 2020), however, it has certainly helped business in reducing their debt-servicing cost on one hand and on the other hand, helped the government in keeping the fiscal deficit nearer to the targets.

\section{B. Loan extension and restructuring package}

During the current economic crisis, Governments and conventional central banks stimulus were premeditated to enhance people spending's to increase economic activities, which are ordinarily a mixture of direct assistance to households (e.g., unemployment insurance expansions, tax deferrals, and transfers) and loans to businesses (Martin, 2020). An important ingredient of central banks' response to the crisis was the extensive placement of long-term lending measures to support the liquidity flow to households and businesses. The Federal Reserve, the Bank of England, and the Bank of Japan introduced focused lending programs designed to provide funds to the business and households at favorable terms and conditions (Paolo Cavallino, 2020). The European Central Bank (ECB) has extended its "targeted Longer-Term Refinancing Operations (TLTROs)" and introduced a comprehensive set of collateral easing measures (ECB, 2020). During the pandemic, many of the businesses were unable to generate their routine and forecasted revenue, due to lockdowns and reduced demand. This eventually crippled their abilities to meet their fixed cost and especially obligations arising out of debt financing. In case the cost of debt servicing is not reduced there was a high risk of defaults which will not only stop the enterprise's contribution towards GDP but will also reduce liquidity and profitability of the Money market.

Just like Pay Check Protection Program (PPP) in the U.S., Quick Loan Programme in Germany's, Coronavirus Business Interruption Lending Scheme for small business in the UK, EMI moratorium of loans in India, special loan and guarantee program by south Korea, the SBP introduced its loan extension and restructuring package for the businesses (Mosser, 2020) (Sungho Park, 2020). Loan Extension and Restructuring Package (Debt relief scheme) was pronounced to expedite the borrowers in restructuring and adjourning and/or reducing their debt servicing, to preserve the solvency of the borrowers and empower them to contest the momentary economic distractions. Since the launch of the scheme in April 2020 the SBP has restructured or deferred the loans of 867 billion PKR by facilitating more than 1.5 million applicants (SBP, 2020).

\section{Temporary Economic Refinance Facility (TERF)}

To cope with the unusual demand for liquidity during the pandemic, the central banks rapidly stretched their lending operations. Substantial liquidity endowment and targeted credit support to the economy play a vital role in stabilizing financial conditions (Mosser, 2020). Instead of direct liquidity assistance to the businesses, a number of central banks in both developed and emerging economies have launched or reinstated funding-for-lending programs for the provision of credit to the non-financial sector. 
The Central bank of Brazil (Banco Central do Brazil) initiated the 'Working Capital for Business Continuity' (CGPE) program to provide asset-based credit facilities to micro and small and medium-sized companies and has extended BRL 120 billion till November 2020 (BCB, 2020). The European Central Bank (ECB) has extended more than 1 trillion Euro to commercial banks so that they can provide credit facilities to private businesses and households. The ECB also expanded the catalog of assets that banks can use as collateral as well as soften the measures used by banks to determine the value of assets (known as a "haircut") (ECB, 2020).

Temporary economic refinance facility (TERF) is a mode of concessionary refinance facility launched by SBP to provide adequate liquidity in the economy to help the businesses in combating economic implications due to covid-19. As per TERF'criteria, financing is available for the purchase of new imported and locally manufactured plant and machinery. Since the launch of the scheme in April 2020 the SBP has disbursed 441 billion PKR to facilitate private investors from numerous economic sectors (SBP, 2020). It is the only embattled credit package to cope with crisis and provides collateralized, but nonrecourse, funding to private investors for new securitizations and ventures (Mosser, 2020).

\section{SBP Employment Protection Scheme (Rozgar Scheme)}

The eruption of the pandemic caused the vilest economic crisis since the World War II, resulting in stoppage in many businesses, besides other factors caused the prolonged duration of joblessness and force the employers to terminate employees. Resultantly, millions of employees across the globe lost their jobs, while those who are fortunate enough to uphold their jobs have experienced cuts in working hours and pays due to lockdown and restricted movements undergo massive cut in wages and other benefits. The pandemic cast a substantial impact on unemployment in every country, industry, and demographical areas. Just during March 2020, it was noted that more than 10 million Americans lodged unemployment insurance claims, which is $900 \%$ higher than February 2020 (Sydney C. Ludvigson, 2020). From March 2020 to April 2020 unemployment rate in the United States amplified from $4.4 \%$ to over $14.7 \%$ and in Australia, the effective rate of unemployment augmented from 5.4 to $11.7 \%$ (Aino Suomi, 2020)

Many Central banks have launched employment protection schemes to support the companies for payroll payments. The Central bank of Brazil (Banco Central do Brasil) has saved 12.2 million employments from 1.4 million companies by launching a 40 billion BRL emergency line to support the payroll costs of small and medium-sized enterprises (SME), The companies who availed financing under this scheme are not be allowed to fire their workers (BCB, 2020)

To protect employees from job sufferings the State Bank of Pakistan launched an employment protection scheme (SBP Rozgar Scheme). The purpose of this scheme is to support the employers in avoiding layoffs during the liquidity crunch caused by the lockdown. The scheme helps employers by granting concessional credits to businesses for salaries and wages for the permanent, contractual, and daily wagers, provided that if the employers commit not to lay off their workforce. it has been revealed that over 1.8 million employees from more than three thousand businesses have got their employment protected by this scheme. Up till November 13, 2020, the SBP has suctioned the Rupees 238 billion at interest rate ranging from $0 \%$ to $5 \%$. (SBP, 2020)

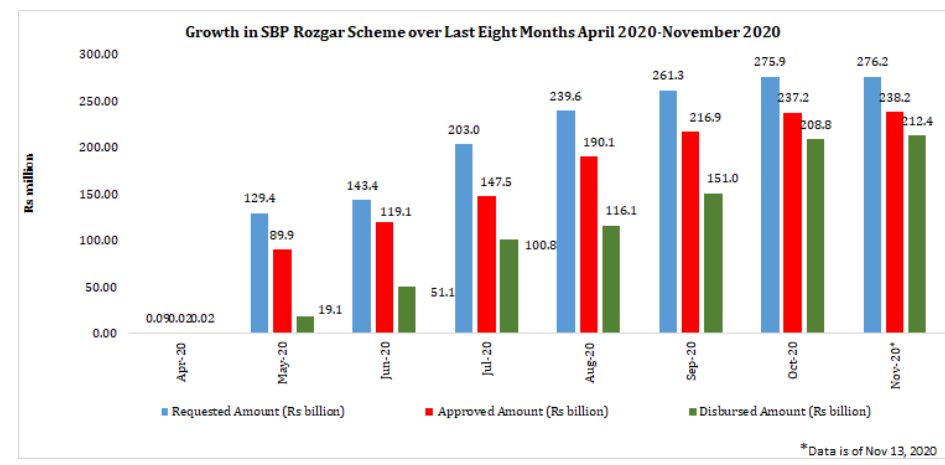

Fig.2. Growth in SBP Rozgar Scheme from April 2020 November 2020

\section{E. Supporting to the health sector to Combat the Virus}

Supportive health financing policies are inevitable in order to strengthen the frontline services to cater the pandemic. The COVID-19 crisis has drawn attention to already overburdened public health systems in many countries and highlighted the robust need for sustainable investment in health systems. The European Central Bank (ECB) has announced the Pandemic Emergency Purchase Programme of $€ 750$ billion to stimulate and support the health sector (ECB, 2020). The European Union approved a package of $€ 540$ billion for "Pandemic Crisis Support" based on existing precautionary for member countries to finance health-related spending (Dorine Boumans, 2020)

The State Bank of Pakistan launched the Refinance Facility for Combating COVID-19 (RFCC), intended to enhance the capability of the health sector to cater the health emergency specifically in the backdrop of COVID-19. All hospitals and medical centers throughout the country are entitled to avail this financing facility to combat COVID-19 and to augment their capabilities and competencies to cater the health emergencies. Further, the manufactures and importers of protective gears i.e., face masks, testing kits, protective dresses, and other items of similar nature are also eligible to enjoy the benefits of this refinancing facility. Up till November 19, 2020, the SBP has suctioned the Rupees 7.7 billion at interest rate ranging from $0 \%$ to $3 \%$. (SBP, 2020) 


\section{F. Digitalization of Payment Mechanisms and Operating Procedures}

COVID-19 is driving digitalization to novel elevations especially in payments (Anton N. Didenko, 2020). The current pandemic has stimulated electronic payments in such a manner that have never evolved before. The pandemic urges central banks to impute dramatic changes in the traditional concept of money and payment systems by introducing electronic and digitalized payments mechanisms (ÖZSOY, 2020). An example is the current proposal for the US House emergency Covid-19 stimulus bill, which discussed to introduce a 'digital dollar' to get stimulus payments to unbanked Americans. (USA-government, 2020)

As Covid-19 unfolds, many governments encouraged direct financial transfers to businesses and households beyond traditional social protection mechanisms. The transmission of the payment message and the availability of final funds to the payee occur in real-time (or close to it) on as close as possible to a 24-hour, seven-day basis. In many developing countries, the volume and scale of direct transfers is unprecedented. In Peru and Argentina for instance, these direct transfer programs cover one-third of their total populations, and in the Philippines, more than $70 \%$ of households receive emergency transfers (Michal Rutkowski, 2020) (Biagio Bossone, 2020).

To expedite transactions through digital means, SBP has renounced all the transactional fee charged by banks for interbank and intra-bank fund transfers through online banking channels, further the bank also waived charges against all customer transfers performed through SBP operated RTGS system (SBP, 2020).

Central banks of many countries i.e., Brazil, Egypt, Ukraine, and the United Kingdom have simplified customer due diligence for opening a new bank account. In Peru, financial institutions now may open accounts, without requiring them to sign a contract (Patrick Meagher, 2020). Similarly, to fascinate the users towards online banking channels, SBP also surrendered the prerequisite of biometric verification for activation of mobile and internet banking. (SBP, 2020).

Central Bank of Iran (known as Bank Markazi) launched a "digital/application-only policy" for some banking activities which has increased the electronic and mobile banking services users up to twenty percent. The said bank has also enhanced the limit for electronic and online transactions to encourage the use of e-banking services and to control the circulation of paper currency. The Qatar Central Bank (QCB) introduced Qatar Mobile Payment System (QMP) to provide a safe and innovative mechanism to carry out immediate electronic payments. (Atashbar, 2020).

SBP offered a Direct Cheque Deposit Facility (DCDF) which has reengineered the process of clearing of cheques, as the banking industry faced gigantic pressure to facilitate the financial necessities of the customers due to shrinkage in operational timings and successive closure of some of the branches. The DCDF not only lessened the processing time but also offered a prospect to customers to avail real-time gross settlement systems (RTGS) facility operated by SBP. In this facility, instead of visiting their respective branch, the customers can present crossed cheques to any branch of their bank, to have immediate transfers of funds to their account. Further, for the ease of customers, SBP also introduced (i) Doorstep Cheque Collection Facility (ii) Dropbox Cheque Collection Facility (iii) Clearing of scanned image of the cheque for priority/corporate customers (iv) Image-Based Clearing (IBC) functionality (SBP, 2020)

\section{G. Relaxing Credit Requirements for Exporters and Importers}

The outbreak of COVID-19 led to lockdowns in various countries caused the stagnation of economic activities around the globe. The closure of borders interrupted cargo of goods and disrupted across border services which triggered the breakdown of the supply chain. Sustaining the cross-border trade activities during the pandemic are critical to provide crucial food and health supplies and to limit the adverse impacts on jobs and employments. Many countries countered to the COVID-19 pandemic with a combination of import and export liberalization, trade-facilitating measures for health supplies, and personal protective equipment (PPE) i.e., facemasks, ventilators respirators, etc. The purpose of these actions is to maximize the availability of necessary substances to combat the pandemic. (Hoekman, 2020). The SBP took the following measures to facilitate imports and exports during the pandemic.

Relaxation in Conditions for Long Term Financing Facility: Before the pandemic, the exporters were required to have exports worth 50 percent of total sales, or USD 5 million in order to avail credit under "Long Term Financing Facility (LTFF)". The SBP reduced the limit to 40 percent of sale or USD 4 million for all the borrowings under LTTF during the period January 01, 2020, to September 30, 2020, to support the cash flows of the exporter during the pandemic. (SBP, 2020).

Relaxation of Performance Requirement under Export Finance Scheme (EFS): Before COVID-19 exporters were required to export twice than the amount of borrowed funds to avail cheaper credit under the export finance scheme. The performance requirement has been reduced from twice to oneand-a-half times during the current fiscal year 2020/21. (SBP, 2020).

Extension in Time for Realization of Proceeds: SBP enhanced the time period for realization of exports proceeds from 180 days to 270 days where the delay is related to COVID-19. The purpose of this extension is to support the exporters to provide extended credit limits to the buyers by domestic exporters. Similarly, The Central bank also extended 


\section{International Journal of Engineering Applied Sciences and Technology, 2021 \\ Vol. 6, Issue 1, ISSN No. 2455-2143, Pages 99-105 \\ Published Online May 2021 in IJEAST (http://www.ijeast.com)}

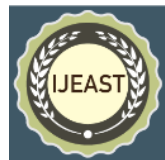

the time period for the import of goods against advance payment from 120 days to 210 days. (SBP, 2020)

Direct Dispatch of Shipping Documents: Before COVID-19, the exporters were allowed to despatch shipping documents directly to foreign customers only if the value of consignment was less than 100,000 USD. Now the exporters can despatch shipping documents directly to the foreign consignees or their agents without any limit or restriction. (SBP, 2020)

Advance Payment for Imports Increased: In order to support and facilitate the importers, SBP extended the limit for advance payment against imports from 10,000 USD per invoice to 25,000 USD for import of raw material, spare parts, and machinery. (SBP, 2020)

\section{CONCLUSION}

Regardless Of the distinct nature of the current financial turbulence due to pandemic, central banks have countered the resulting financial chaos with the conventional tools which are being used by the banks historically. But the latitude and velocity of the central bank's policy response to COVID-19 have outstripped the response to all historical financial crises. Central banks have cut policy rates, designed lending programs, and amended financial regulations to support business growth and curtail long-run economic damage. However, many economists warn that the quick growth in the money supply will cause long-term inflation, and the immense debt heaps built up during this pandemic will act as a hindrance to prospective economic growth. Resultantly, this combination could cause stagflation - a stimulating economic situation in which high inflation is tied with low growth.

The pandemic has highlighted the significance of forceful, targeted, and rapid response by policymakers to emerging economic and financial crisis. The prudent and fast measures implemented by the state bank of Pakistan i.e., lowering the policy interest rate, introduction of temporary economic refinance facility, loan extension and restructuring package, employment protection schemes, and other similar types of measures helped to swiftly resolve severe financial stress. These measures also provided immediate support to businesses and households who were facing a decline in incomes and helped to reduce potential long-term harm to economies and financial systems. We tentatively conclude that the monetary policy response has significantly contributed to mitigating the economic consequences of the global pandemic.

\section{REFERENCE}

[1] Aino Suomi, T. P. (2020). unemployment, employability and covid19: how the global socioeconomic shock challenged negative perceptions toward the less fortunate in the australian context. Frontiers in Psychology. doi:https://doi.org/10.3389/fpsyg.2020.594837

[2] Anton N. Didenko, D. A. (2020). After libra, digital yuan and covid-19: central bank digital currencies and the new world of money and payment systems., (pp. 20-32).

[3] Atashbar, T. (2020). Covid-19 response in MENA: the challenges and opportunities for the banking sector and financial inclusion. Retrieved from www.internationalbanker.com: https://internationalbanker.com/banking/covid-19response-in-mena-the-challenges-and-opportunities-forthe-banking-sector-and-financial-inclusion/

[4] BCB. (2020). Preserving the regular operation of the financial system and the Brazilian economy. Retrieved from https://www.bcb.gov.br/en/about: https://www.bcb.gov.br/en/about/covid-19-measures

[5] Biagio Bossone, H. N. (2020). Getting funds to those in need and enabling access to money during COVID-19, part 3: Central bank digital currencies and other instruments. Retrieved from www.voxeu.org: https://voxeu.org/article/covid-19-central-bank-digitalcurrencies-and-other-payments-instruments

[6] BOC. (2020). Covid-19: actions to support the economy and financial system. Retrieved from https://www.bankofcanada.ca:

https://www.bankofcanada.ca/markets/market-operationsliquidity-provision/covid-19-actions-support-economyfinancial-system/

[7] BOE. (2020). Our response to coronavirus. Retrieved from https://www.bankofengland.co.uk: https://www.bankofengland.co.uk/coronavirus

[8] Buiter, W. H. (2008). Central banks and financial crises., (pp. 70-82).

[9] CBC. (2020). All COVID-19 measures, step by step. Retrieved from https://www.banrep.gov.co: https://www.banrep.gov.co/en/all-covid19-measures

[10] Cukierman, A. (2013). Monetary policy and institutions before, during, and after the global financial. Journal of Financial doi:http://dx.doi.org/10.1016/j.jfs.2013.02.002

[11] Dave Altig, S. B. (2020). Economic uncertainty before and during the COVID-19 pandemic. Journal of Public Economics. doi:https://doi.org/10.1016/j.jpubeco.2020.104274

[12] Dorine Boumans, S. L. (2020). COVID-19: The World Economy Needs a Lifeline -But Which One?, (pp. 8-13).

[13] ECB. (2020). Our response to the coronavirus pandemic. Retrieved from https://www.ecb.europa.eu: https://www.ecb.europa.eu/home/search/coronavirus/html /index.en.html 


\section{International Journal of Engineering Applied Sciences and Technology, 2021 \\ Vol. 6, Issue 1, ISSN No. 2455-2143, Pages 99-105 \\ Published Online May 2021 in IJEAST (http://www.ijeast.com)}

[14] FED. (2020). Coronavirus disease 2019 (COVID-19). Retrieved from https://www.federalreserve.gov: https://www.federalreserve.gov/covid-19.htm

[15] Hoekman, B. (2020). COVID-19 trade policy measures, G20 declarations and WTO reform., (pp. 30-42).

[16] Jácome, L. I. (2008). Is there any link between legal central bank independence and inflation? Evidence from Latin America and the Caribbean. European Journal of Political

Economy. doi:https://doi.org/10.1016/j.ejpoleco.2008.07.003

[17] Kelly Mua Kingsly, K. H. (2020). Central Banks Respond to COVID-19 to Stave off a Financial Crisis, They Need for Targeted Fiscal Measures Should not Be Understated. doi:https://dx.doi.org/10.2139/ssrn.3562320

[18] Martin, F. (2020). Economic Realities and Consequences of the COVID-19 Pandemic-Part II: The Economy and Fiscal Policy. Economic Synopses. doi:https://doi.org/10.20955/es.2020.11

[19] Michal Rutkowski, A. G. (2020). Responding to crisis with digital payments for social protection: Short-term measures with long-term benefits. Retrieved from www.worldbank.org:

https://blogs.worldbank.org/voices/responding-crisisdigital-payments-social-protection-short-term-measureslong-term-benefits

[20] Mosser, P. C. (2020). Central bank responses to COVID $19 . \quad$ Business Economics. doi:https://doi.org/10.1057/s11369-020-00189-x

[21] OECD. (2020). OECD interim economic assessment Coronavirus: The world economy at risk. In OECD economic outlook. doi:https://doi.org/10.1787/

[22] Paolo Cavallino, F. D. (2020). Central banks' response to Covid-19 in advanced economies., (pp. 1-4).

[23] Patrick Meagher, D. D. (2020). Microfinance and COVID-19: A Framework for Regulatory Response. Retrieved from www.cgap.org: https://www.cgap.org/research/covid-19-

briefing/microfinance-and-covid-19-frameworkregulatory-response

[24] Peterson Ozili, T. A. (2020). Spillover of COVID-19: impact on the Global Economy. doi:https://dx.doi.org/10.2139/ssrn.3562570

[25] SBP. (2020). Countering Covid-19 : Measures by State Bank of Pakistan. Retrieved from https://www.sbp.org.pk: https://www.sbp.org.pk/COVID/index.html

[26] Sungho Park, C. S. (2020). Government Financial Management and the Coronavirus Pandemic:A Comparative Look at South Korea and the United States. American Review of Public Administration. doi:https://doi.org/10.1177/0275074020941720

[27] Sydney C. Ludvigson, S. M. (2020). COVID-19 and The Macroeconomic Effects of Costly Disasters., (pp. 30-35).
[28] The Economist. (2020, Feburary 29). Covid-19 is now in 50 countries, and things will get worse. The Economist. Retrieved from https://www.economist.com/briefing/2020/02/29/covid19-is-now-in-50-countries-and-things-will-get-worse

[29] USA-government. (2020). Congressional Bills 116th Congress. Retrieved from https://www.govinfo.gov: https://www.govinfo.gov/content/pkg/BILLS116s3571is/html/BILLS-116s3571is.htm

[30] ÖZSOY, Ç. Y. (2020). Covid-19 Pandemic And Central Bank Digital Currency As The Future. Ekonomi Maliye İşletme doi:https://doi.org/10.46737/emid.725549D. Kunder, "Multi-resolution Digital Watermarking Algorithms and Implications for Multimedia Signals", Ph.D. thesis, university of Toronto, Canada, 2001. 